\title{
УКРАЇНСЬКА ШКОЛА ЯК ВІДКРИТА СОЦАЛЬНА СИСТЕМА
}

\author{
Доповідь на Всеукраїнському серпневому форумі «Освіта України 30 \\ без бар'єрів: вектори якості та успіху», 19 серпня 2021 р., м. Київ, Україна
}

https://doi.org/10.37472/2707-305X-2021-3-2-17-1

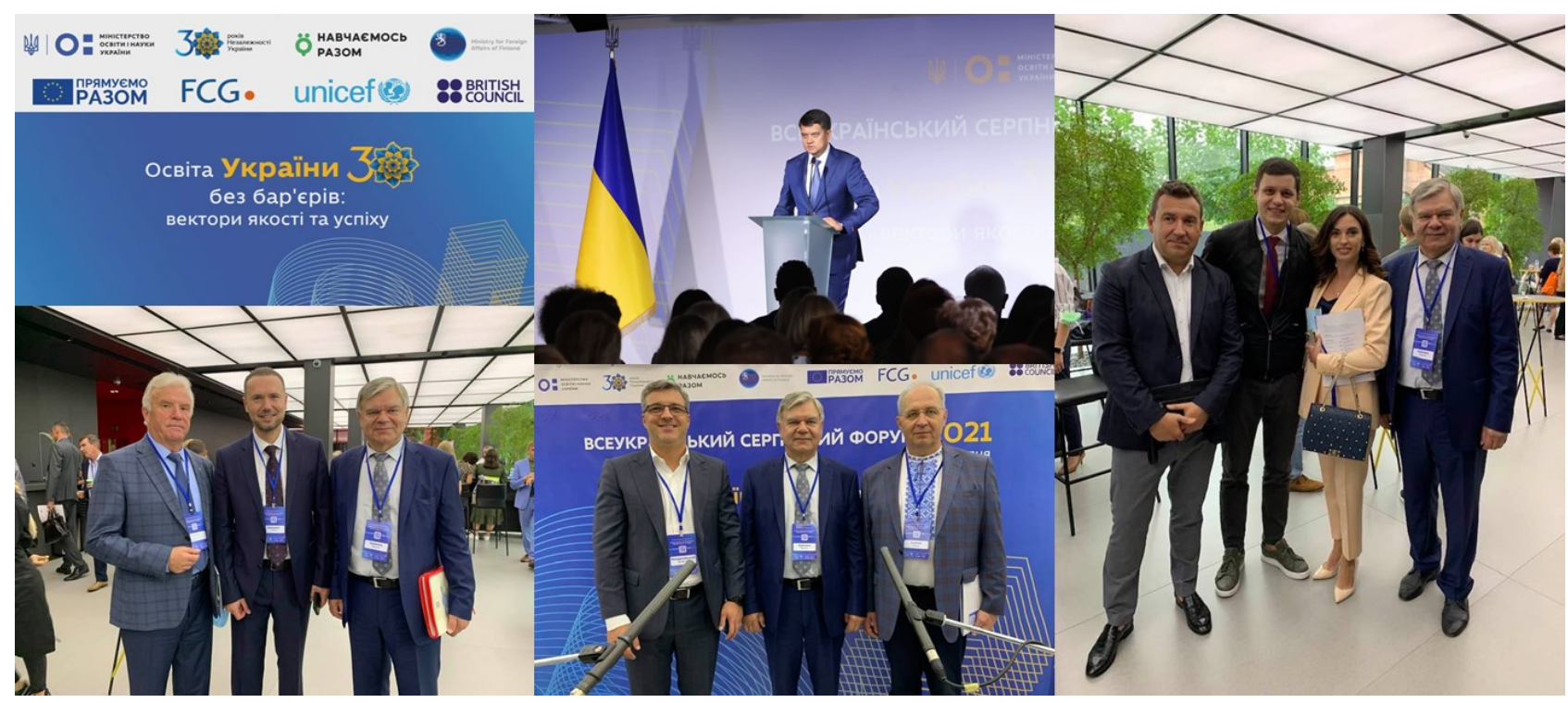

КРЕМЕНЬ Василь Григорович

доктор філософських наук, профессор, дійсний член (академік) НАН України і НАПН України, президент Начіональної академії педагогічних наук України, м. Київ, Україна

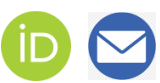

Анотація. У виступі висвітлено проблему утвердження української школи як відкритої громадсько-активної системи. Привернуто увагу до ключових завдань, які необхідно вирішити на шляху реформування загальної середньої освіти в Україні. 3-поміж них: запровадження державно-громадського управління у створенні відкритого простору активної взаємодії української школи; урахування відповідних особливостей, пов'язаних з розширенням сфери застосування цифрових рішень і сервісів, доступністю гаджетів, інтенсивним розвитком соціальних медіа; формування цифрової компетентності здобувачів загальної середньої освіти, вчителів і батьків; міжнародне співробітництво, яке є невід'ємною складовою діяльності школи; унаслідок збільшення інтернет-ризиків забезпечення профілактики кібербулінгу та зменшення кібервіктимізації дітей і підлітків; формування потужного громадського руху обізнаного иифрового батьківства. Схарактеризовано тенденції, які стали притаманними для суспільства та є значущими для активної взаємодії української школи в освітньому й соціальному просторах в умовах функціонування онлайн.

Ключові слова: українська школа; відкрита сочіальна система; цифрова компетентність; кібербулінг; медіаосвіта.

Одним із важливих завдань реформування освіти в Україні $€$ утвердження української школи як відритої соціальної системи. Системи, яка активно взаємодіє з громадою, батьками, учнями, різними закладами і громадськими організаціями, забезпечує «безбар'єрну» соціалізацію учнів, рух школи у напрямах якості та успіху. Українська школа все більше набуває рис громадськоактивної школи. У цьому контексті привернемо увагу до таких актуальних проблем. 
Перше. Одним із пріоритетних завдань у створенні відкритого простору активної взаємодії української школи $€$ реальне запровадження державно-громадського управління.

Вченими Національної академії педагогічних наук України розроблено організаційно-методичні засади та зміст такого управління. Вивчення практики та чинного законодавства показало, що в цьому важливому питанні є невирішені проблеми, зокрема:

- реальний механізм здійснення децентралізації управління загальною середньою освітою, передусім розвитку громадської складової в управлінні в освітньому законодавстві хоч і передбачено, але потребує удосконалення й запровадження відповідно до базового Закону України «Про освіту» (2017р.);

- нормативно-правова база закладів загальної середньої освіти недостатньо сприяє реальному втіленню законодавчо визначеної автономії (кадрової, фінансової, організаційної та змістової), розподілу повноважень і сфер відповідальності суб'єктів управління на різних рівнях управління освітою та територіальних громад;

- забезпеченню високої ефективності демократичних підходів до управління могло б сприяти розроблення Освітнього кодексу України. Тут доцільно використати досвід Франції, де було прийнято у 2000 році Кодекс освіти (Code de l'éducation), який об'єднав усі чинні правові норми, що стосуються освіти.

Друге. Окремо варто зупинитися на особливостях простору активної взаємодії української школи. Сучасна взаємодія людини в цифровому просторі відмінна від взаємодії минулого часу, що безпосередньо пов'язане з розширенням сфери застосування цифрових рішень і сервісів, доступністю ґаджетів, інтенсивним розвитком соціальних медіа.

Природно, що така ситуація зумовлює необхідність змін в усталених методичних практиках як на рівні школи, так і сім'ї.

За даними Державної служби статистики України за 2020 рік 94 \% хлопців і дівчат у віці від 15 до 18 років користуються інтернетом щоденно, а діти у віці до 15 років - $80 \%$. Оскільки інтернет повністю інтегрований у життя підлітків та старшокласників, цифровий і фізичний світи не можна розглядати окремо. 3 огляду на це потрібна державна освітня політика у створенні безпечного, інклюзивного, дитиноцентрованого простору 3

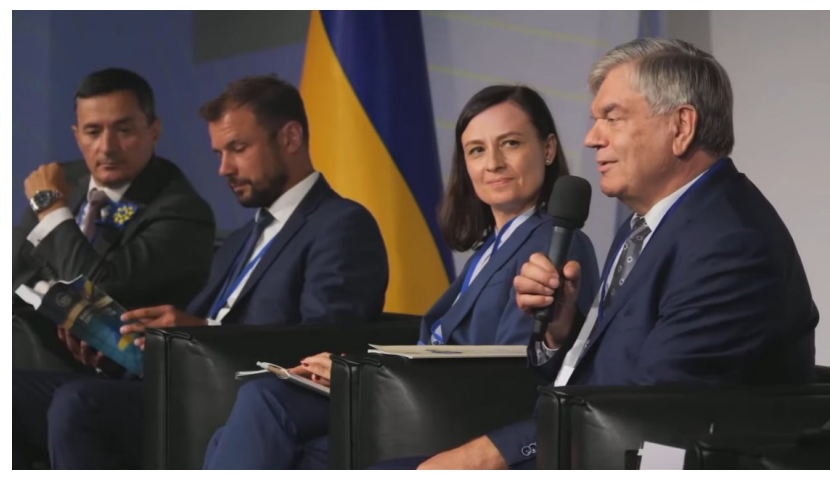

можливістю отримання індивідуально підібраного контенту, побудованого на нормах загальнолюдської та національної моралі й етики.

Принципово важливими інформаційно-методичними ресурсами цифрового освітнього простору української школи мають стати: вебсайт або портал; віртуальний методичний кабінет, мережеві методичні об'єднання педагогічних працівників; електронні портфоліо керівників, педагогічних працівників і здобувачів освіти; структурована медіатека; віртуальна бібліотека.

Хочу зазначити, що 10 років тому Інститутом інформаційних технологій і засобів навчання НАПН України на базі системи EPrints було створено Електронну бібліотеку НАПН України (lib.iitta.gov.ua), в якій у відкритому доступі представлено результати наукових досліджень установ Національної академії педагогічних наук України і яка активно використовується педагогами: близько 25 тис. ресурсів, кількість завантажень - понад 8 млн. До речі, цим ресурсом послуговуються фахівці зі 181 країни світу.

Tpemє. Для активного використання можливостей цифрового простору, вільного орієнтування в сучасному світі необхідно сформувати цифрову компетентність як здобувачів загальної середньої освіти, так і вчителів, і батьків.

Вченими НАПН України з метою підвищення рівня цифрової компетентності педагогів розроблено та запроваджено освітні курси: «Виховні можливості цифрового простору», «Основи медіаграмотності та критичного мислення як складові цифрової компетентності», «Плюси і мінуси інтернет-колаборації» та ін.

На допомогу керівникам, учителям, батькам вчені Академії у співпраці з практиками розробили Концепцію виховання дітей та молоді у цифровому просторі, як систему науково обґрунтованих положень, що визначають суспільні виклики й стратегічні напрями виховання молодого покоління в умовах цифрової реальності. Концепцію 
розміщено на сайті Академії для громадського обговорення, і ми будемо вдячні за слушні пропозиції та зауваження.

Четверте. Міжнародне співробітництво $€$ невід'ємною складовою діяльності школи. Його пріоритетним завданням є підготовка та реалізація міжнародних проєктів у сферах освітнього та культурного обмінів, залучення коштів міжнародних фондів та організацій із метою підвищення ефективності освітньої діяльності та якості навчання до рівня кращих світових практик. У цьому відношенні ми повинні сповна використати в інтересах України розширення на сферу загальної середньої освіти нової програми ЄС Еразмус+ на 2021-2027 роки.

Осмислення європейських та загальнолюдських цінностей у процесі активного діалогу з однолітками, викладачами, експертами з країн $\in C \in$ важливим механізмом формування європейської ідентичності та свідомої підтримки українською молоддю європейського і євроатлантичного курсу нашої держави.

Пандемія COVID-19 виступила потужним каталізатором розвитку інтернаціоналізації освітніх процесів у дистанційному та цифровому форматі. Разом із тим, необхідною передумовою успішної цифрової інтернаціоналізації освіти української учнівської молоді $€$ забезпечення належного рівня матеріально-технічної бази закладів освіти для інтенсивної комунікації із закордонними колегами.

П'яте. Слід зазначити, що упродовж останніх двох років збільшилися майже всі інтернет-ризики.

У 2020 році понад 80 \% дітей наражалися хоча 6 на один із видів кібербулінгу. За нашими дослідженнями небезпечними є рольові комп'ю- терні ігри, які здатні сформувати психологічну залежність. Всесвітня організація охорони здоров'я (ВООЗ) внесла комп'ютерну залежність у розряд категорій патологічних пристрастей. Доведено, що до 14 \% користувачів Інтернету мають психологічну залежність. Така ситуація перетворила кібербулінг на гостру освітню проблему.

Дослідження вчених НАПН України показали, що головною стратегією протидії кібербулінгу наявних і прогнозованих видів залишається комплексне охоплення профілактикою та просвітою всіх суб'єктів.

Слід підкреслити, що ефективне виховання в цифровому просторі потребує керування принци пом реальності, опертя на дослідження, а не на суб'єктивні, часто хибні, уявлення і відчуття щодо профілактики кібербулінгу та зменшення кібервіктимізації дітей і підлітків.

Шосте. Вважливим суб'єктом простору активної взаємодії школи є батьки. Вченими нашої Академії розробляється науковий психолого-педагогічний супровід розвитку здоров'язбережувальної сімейної медіаосвіти як форми підтримки системи освіти дитини в цифровому середовищі.

Ми пропонуємо інтегрувати зусилля для створення на національному і локальних (місцеві громади, заклади освіти) рівнях проєктів сімейної медіаосвіти, які сформували 6 потужний громадський рух обізнаного цифрового батьківства.

I останнє. Вченими Академії досліджено тенденції, які стали характерними в суспільстві та $€$ значущими для активної взаємодії української школи в освітньому й соціальному просторах в умовах функціонування онлайн. Серед них:

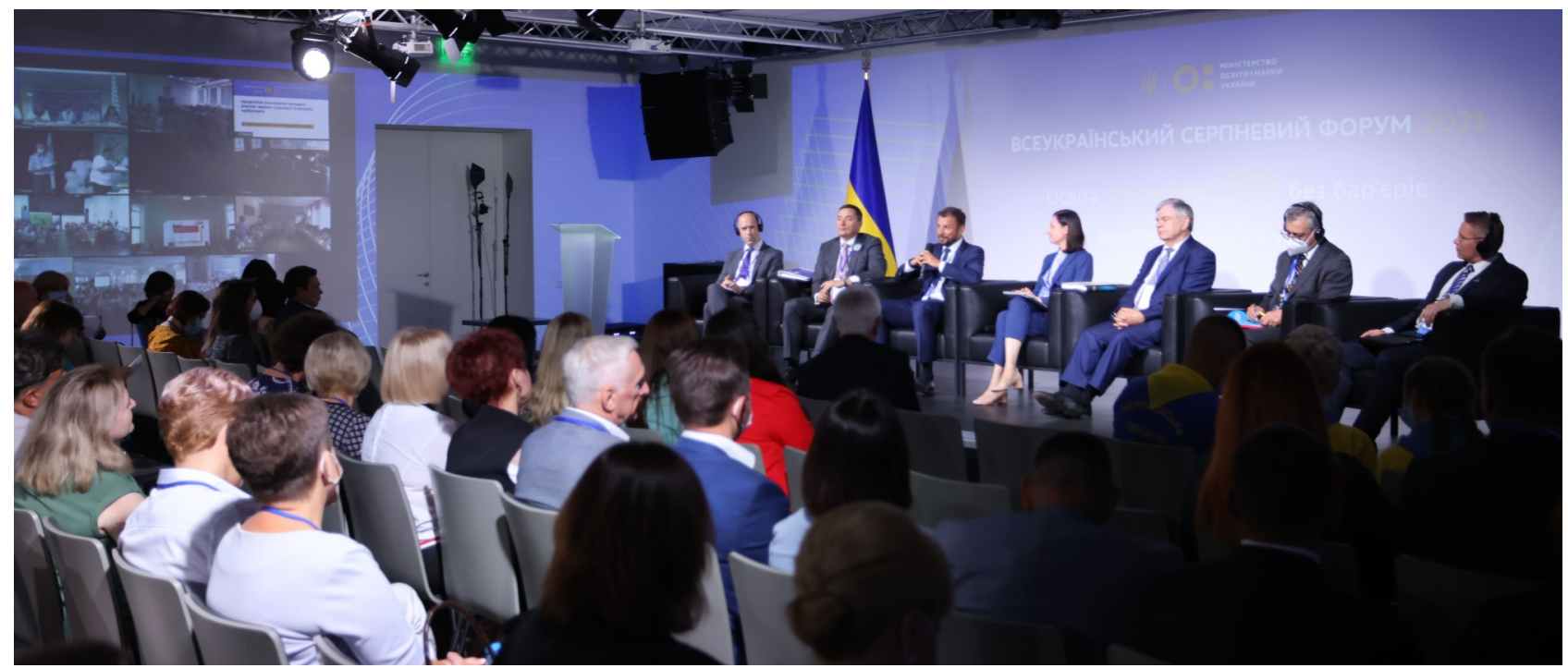


Тенденція до переосмислення трудової діяльності в режимі «онлайн». Робота колективів проілюструвала їхню здатність до змін, мобільність або ж, навпаки, невміння швидко реагувати на виклики часу. Запорукою успішності стала професійна мобільність та адаптивність.

Зростаюча роль самоосвіти та самоорганізації: переважна більшість педагогів і учнів певною мірою в обмежені терміни оволоділи необхідними знаннями, закріпили навички та знайшли ресурси для того, щоб продовжити працювати в умовах, що змінилися.

Стала очевидною роль мотивації до навчання ma педагогічної діяльності.

Утверджується роль учителя як тьютора, але й поглибилося розуміння ролі педагогічного супроводу, особистого спілкування, впливу педагога на особистість дитини.

Зросла роль спільнот - однодумців: людей, які не обов'язково пов'язані професійними інтересами або працюють в одній організації, а орієнтовані на досягнення спільно значущого результату. Такі спільноти можуть включати в себе батьків, педагогів, волонтерів, методистів, науковців, програмістів, психологів.

Відбувається створення реально функціонуючої системи дистанційної взаємодії, формується банк навчальних матеріалів і ресурсів.

Стало очевидним, що цифрова компетенція $\epsilon$ ключовою для людини і суспільства в XXI cmoлimmi.
Аналіз свідчить, що чим більш яскравою буде палітра складових простору активної взаємодії української школи, тим більш потужною і якісною буде наша освіта.

В єднанні різноманіття - наша сила!

\section{СПИСОК ВИКОРИСТАНИХ ДЖЕРЕЛ}

Міністерство освіти і науки України. (2021, 19 серпня). При реформуванні сфери освіти ванливий діалог та зворотний зв'язок від освітян, - Голова Верховної Ради Дмитро Разумков. https://cutt.ly/2WejtnN

Міністерство освіти і науки України. (2021, 19 серпня). Місія освіти полягає у формуванні людського капіталу, - Міністр Сергій Шкарлет під час Всеукраїнського серпневого форуму. https://cutt.ly/ HWejIKL

Міністерство освіти і науки України. (2021, 19 серпня). Виклики COVID-19, іноземний досвід, розвиток педагогів - партнери МОН обговорили можливості для розвитку освіти України під час Серпневого форуму. https://cutt.ly/aWejnKV

Національна академія педагогічних наук України. (2021, 17 серпня). Проєкт "Концепиії виховання дітей та молоді в цифровому просторі» представлено для обговорення. https://naps.gov.ua/ua/ press/releases/2384/

Національна академія педагогічних наук України. (2021, 19 серпня). Всеукраїнський серпневий форум «Освіта України 30 без бар'єрів: вектори якості та успіху»: сесія "Нова Українська школа». http://naps.gov.ua/ua/press/releases/2389/

Code de l'éducation. (2000). Légifrance. https:// www.legifrance.gouv.fr/codes/id/LEGITEXT000006071191/

MON UKRAINE. (2021, 19 серпня). Всеукраїнський серпневий форум «Освіта України 30 без бар'єрів: вектори якості ma успіху» [Відео]. YouTube. https://youtu.be/IIrHED85xnw

\section{UKRAINIAN SCHOOL AS AN OPEN SOCIAL SYSTEM \\ Report at the All-Ukrainian August Forum "Education in Ukraine 30 Without Barriers: Vectors of Quality and Success", August 19, 2021, Kyiv, Ukraine}

Vasyl Kremen

DSc in Philosophy, Professor, Full Member (Academician) of NAS of Ukraine and NAES of Ukraine, President, National Academy of Educational Sciences of Ukraine, Kyiv, Ukraine

Abstract. The problem of strengthening the Ukrainian school as an open socially active system is enlightened in the speech. The key tasks are highlighted, which should be addressed through reforming the general secondary education in Ukraine. Among them: introduction of public and state administration in creating an open space for active interaction of the Ukrainian school; taking into account the relevant features associated with the expansion of the scope of digital solutions and services, availability of gadgets, intensive development of social media; development of students', teachers' and parents' digital competence; international cooperation, which is an integral part of the school; due to increased Internet risks ensuring cyberbullying prevention and reducing cyber-victimization of children and adolescents; forming a powerful social movement of aware digital parenting. The trends which became inherent in society and are important for active interaction of the Ukrainian school in educational and social spaces under online operation are characterized.

Keywords: Ukrainian school; open social system; digital competence; cyberbullying; media education. 